\title{
A POSSESSÃO COMO PRÁTICA: ESBOÇO DE UMA REFLEXÃO FENOMENOLÓGICA
}

Miriam Rabelo

\section{Introdução}

Trabalhos contemporâneos sobre a possessão têm se afastado de modelos explicativos reducionistas em direção a abordagens mais contextualizadas, preocupadas em entender a possessão em termos da experiência vivida por muitos povos e grupos que cultivam interações com espíritos e deuses. Estudos têm tratado dos modos com os quais a possessão permite aos indivíduos reenquadrar e redirecionar relacionamentos (Lambek 1981, 1993; Boddy 1989), assumir certa distância em relação à ordem cultural dominante (Corin 1998; Boddy 1989), construir a identidade e articular formas de agência (Crapanzano 1977, 1992; Stoller 1997; Corin 1998; Masquelier 2001). Apesar da diversidade das fontes etnográficas e dos distintos modelos analíticos empregados, os estudiosos do tema parecem compartilhar uma compreensão da possessão como uma prática (atividade moral, crítica corporificada de arranjos dominantes de poder, práxis mimética etc.).

Esta idéia é promissora — reverte o foco anterior para a explicação das causas da possessão e conduz a atenção para sua construção e seu uso em contextos interativos diversos. Entretanto, também coloca a necessidade de um exame da teoria da prática que, implícita nas análises, orienta suas principais conclusões. Neste trabalho, discuto três pontos inter-relacionados que me parecem cruciais para qualquer teoria da prática: a questão da agência, a das relações entre corpo e significado e a da temporalidade, ou melhor, do papel do passado na conformação da prática. Ao partir de uma abordagem fenomenológica, e valendo-me mais especificamente de algumas reflexões de Merleau-Ponty — provavelmente o filósofo desta tradição que tem exercido influência mais direta na teoria antropológica contemporânea desenvolvo o argumento de que um tratamento apropriado destas três questões (e não apenas da terceira) requer a atenção à constituição temporal da 
prática, neste caso, da possessão. Mais especificamente, argumento que a falta de uma reflexão sobre a temporalidade pode conduzir a sérias distorções na análise da possessão.

Devido àquilo que muitas teorias nativas consideram como características dominantes da possessão - perda total ou parcial da consciência, renúncia do comando sobre o próprio corpo e vontade e sujeição a poderes enraizados no passado - a possessão oferece um caso bastante interessante para debatermos certos pressupostos subjacentes à teoria da prática. Vou abordar estas questões através de uma discussão da possessão no candomblé, mais particularmente examinando as trajetórias de três pessoas iniciadas em terreiros de Salvador. Vale notar que o objetivo deste texto não é discutir e confrontar diferentes abordagens em relação à possessão no contexto afrobrasileiro, ou mesmo oferecer uma visão alternativa do tema, mas levantar, a partir da discussão de casos e eventos, algumas questões teóricas para um entendimento da possessão como prática.

\section{Possessão e a questão da agência}

Em colocação que resume uma linha significativa de interpretação da possessão no candomblé, Prandi (1991) observa que nos cultos afro-brasileiros o fiel é gradativamente introduzido em uma série de papéis religiosos que passa a incorporar em ocasiões prescritas; "eus sagrados" que expandem sua experiência de si. Conclui que

[...] essa multiplicação de eus repara a condição social inferior de origem do neoconverso e o mostra a si mesmo como alguém que agora encontra uma porta pela qual adentrar uma nova vida, como uma imagem de múltiplas, complementares e verdadeiras faces que se criaram escondidas na sua interioridade, e que são uma coisa só - exatamente no momento em que as fronteiras entre a vida e a vida pública do adepto do candomblé ficam abolidas na rotina do terreiro (Prandi 1991:142).

Trata-se de uma experiência de poder que libera da culpa e eleva o fiel acima de uma condição por vezes marginalizada (ver também Bastide 1985; Lépine 1978). A possessão no candomblé, portanto, canaliza fenômenos subjetivos, confere-lhes uma forma cultural e permite sua expressão em contextos legitimados socialmente. Assim fazendo, torna-se um veículo para o fortalecimento dos médiuns e para a constituição da agência. Para refletir melhor sobre esta questão, relato uma história de possessão e iniciação em um terreiro de candomblé. 
Moradora de um dos bairros populares mais densamente povoados de Salvador, Ritinha tem dois filhos pequenos que vivem com ela e seu atual companheiro. Tem 28 anos, é negra e robusta, em geral extrovertida e bemhumorada. Como ela mesma reconhece, é dona de um temperamento forte e "não leva desaforo para casa". Quando adolescente, esteve internada em um hospital psiquiátrico, tida como maluca. Hoje em dia, iniciada no candomblé, está ingressando na carreira de mãe-de-santo. Seu caboclo, Boiadeiro, atende a uma clientela crescente, e Ritinha já promoveu duas sessões em sua casa. Conforme pude notar nessas ocasiões, seu investimento está sendo bem-sucedido. Ritinha contou-me sua história durante uma série de encontros, muitas vezes em conversas informais envolvendo também amigas da vizinhança. Cresceu no meio do candomblé: sua mãe era filha-de-santo e freqüentadora ativa de um terreiro no bairro. Quando ela faleceu, ainda menina foi morar com uma tia evangélica. Logo começou a ter ataques, considerados inicialmente como epilepsia. As crises tornaram-se freqüentes; os exames médicos não confirmaram o diagnóstico de epilepsia e muitas dúvidas pairaram em torno da origem do problema. Para a tia, tratava-se de "coisa do diabo", manifestação que ela combatia espancando a sobrinha para expulsar o demônio. As crises impediam Ritinha, já adolescente, de trabalhar e ajudar no orçamento da casa. Para pôr fim ao problema, a tia decidiu, então, interná-la. Ritinha tinha apenas 15 anos.

Após uma semana, graças à interferência de seu pai, Ritinha terminou por receber alta do hospital. Convencido de que a filha tinha problema de santo, dado seu passado familiar, ele a levou para algumas conhecidas casas de candomblé da cidade até que, durante uma cerimônia realizada em um terreiro da vizinhança, Ritinha "virou no santo" (foi possuída). Foi feita (iniciada) neste terreiro. É filha de Obaluaê, mas foi com o caboclo Boiadeiro que estabeleceu vínculos fortes. A dimensão vivida da possessão guarda uma "qualidade" própria que ela descreve à luz de uma metáfora retirada do domínio das relações amorosas:

Quando o caboclo sai, sinto um vazio. Vou dizer: você gosta de um rapaz, certo? Aí você com aquele rapaz transa, aí quando você está ali com ele, você... está se sentindo forte, né? Quando ele sai, você se sente assim, só, se sente assim abandonada, se sente assim vazia... É assim que eu me sinto quando esse caboclo vai embora, é assim que eu me sinto.

Devido a seu temperamento rebelde, Ritinha nem sempre se acomodou às prescrições da sua religião. Tentou algumas vezes afastar-se do candomblé, mas não foi bem-sucedida. Em uma dessas ocasiões, sofreu nas mãos 
de Boiadeiro. Em um dia de festa no terreiro de seu pai-de-santo, quis sair para beber e dançar com amigas. Decidiu deixar de lado as obrigações religiosas para se divertir, mas no caminho da farra foi possuída por Boiadeiro. O caboclo conduziu-a para o mato, fez com que rasgasse sua roupa e se cobrisse de folhas de cansanção (urtiga). Foi assim que chegou ao terreiro para experimentar ainda mais sofrimento. Em meio a todos os presentes, o caboclo deu-lhe uma chimba (surra), lançando-a violentamente contra o chão e fazendo-a bater a cabeça contra a parede.

Ritinha relaciona os acontecimentos de sua vida com o santo. Não consegue se manter em um emprego por mais de um ano, pois algo sempre acontece que a afasta do trabalho. Diz que essa é a vontade do santo: que ela trabalhe só para ele. Explica que tem um cargo de mãe-de-santo. Está investindo seriamente nessa carreira. Começou dando consulta, jogando os búzios para clientes eventuais e fazendo trabalhos de limpeza. Agora também já dá sessão em sua casa. Em geral trabalha com Boiadeiro. É assistida nesse empreendimento por uma amiga da vizinhança, Marina, que se diz madrinha do caboclo. A segunda sessão que deu em sua casa e que descrevo abaixo foi considerada um grande sucesso:

A pequena sala da casa de Ritinha (construída sobre a laje de sua irmã) estava toda arrumada para a sessão. No centro, a mesa coberta com uma toalha branca exibia um vaso de flores, contas e búzios arrumados para jogo, um copo com água, velas e pratos de comida (bolo de chocolate, pipoca, milho branco e coco ralado, acaçá), folhas e pipocas soltas. Nas paredes havia galhos com folhas verdes, fios de mariô (folhas de palmeira desfiadas) na janela e na porta. O chão estava quase todo coberto de folhas. A sessão começou com as rezas entoadas por Ritinha, sentada à mesa, junto com outras quatro pessoas. Havia uma pequena platéia ao redor, umas seis mulheres. Às rezas católicas seguiram-se os cantos de candomblé. Marina incensou a casa, a configuração se desfez e começou o xirê, a roda de adeptos que cantam e dançam para chamar os orixás no começo das festas. Eram poucas pessoas na roda, um homem tocava o atabaque, na verdade, um balde improvisado para este fim. A esta altura a pequena sala já estava lotada e João, o pai-de-santo de Ritinha, ajudava-a a cantar para os orixás. Depois destes, foi a vez dos caboclos. João puxava os cantos; dois caboclos se fizeram logo presentes: o de Ritinha e o de um rapaz de Obaluaê. A mesa foi empurrada para o canto e as poucas cadeiras retiradas da sala: era preciso dar espaço aos caboclos. Boiadeiro cantava e dançava, a animação era geral. Depois abraçou um por um os presentes e foi ver o povo que se amontoava do lado de fora. Quando voltou a dançar, puxou para si um dos homens, irmão-de-santo e amigo de Ritinha, e depois de lhe dar um abraço, colocou-lhe o chapéu de 
couro na cabeça. Aos poucos o homem começou a tombar, até que seu caboclo chegou. Boiadeiro se animou e pegou uma menina de Iansã, que logo virou, e depois um rapaz de Oxossi. Então, foi pedir cerveja e serviu o pai-de-santo. Quando novamente saiu da sala, uma vizinha de Ritinha foi falar com ele, chamando-o carinhosamente de Bóia. Além dela, outras pessoas tratavam-no com intimidade - Bóia - e riam das coisas que ele falava. De volta à sala, Bóia deu início ao trabalho. Com isso, formou-se uma fila de pessoas para tomar o passe do caboclo - embora o caboclo do irmão-de-santo de Ritinha também estivesse dando passe, as pessoas disputavam para serem atendidas por Boiadeiro. A festa continuou regada a muita cerveja.

Embora Boiadeiro não lhe permita cobrar pelos trabalhos, pois é parte de sua missão dar atendimento gratuito durante um tempo, sempre recebe um agrado dos clientes satisfeitos, o que permite à Ritinha comprar material para a sessão (charutos, perfume etc.) e reservar um pouco para a casa e os filhos. Também pretende juntar dinheiro para fazer sua obrigação de sete anos no candomblé. Com este fim, Marina abriu uma conta no banco para a amiga com o dinheiro do caboclo. Boiadeiro não cobra ("dá quem quiser e o que quiser"), mas pede cerveja: ele e Marina são capazes de tomar todo um engradado após a realização de um trabalho. Seu gosto pela bebida já tem provocado algumas críticas. Ritinha explica:

Toda a vida ele bebeu, quer dizer, botaram o caboclo desse jeito, agora vão querer mudar? Não pode. Toda a vida ele foi isso, agora chamam ele de pedante, chamam ele de mascarado... porque ele chega, quer tomar a cachaça dele e acabou, aí chamam ele de pedante, que ele é mascarado.

Também é farrista notório, dado a samba e paquera: "ia para os candomblés beber, quando não, saía, pegava a mão de uma menina chamada Ninha e ia para o bar beber". Marina ri e acrescenta: "Eu também gosto de sambar muito com ele, qualquer caboclo que me tira, eu fico toda dura, dou aquela rodadinha, engano, já vou saindo, mas com ele não, e ele disse que sambar, só quer comigo".

Os modos de Boiadeiro são, em grande medida, discrepantes em relação ao comportamento esperado de uma mãe de família. Além de apreciador de farra e bebida, o caboclo não demonstra afetividade para com as crianças de Ritinha; ao contrário, as suas traquinagens tiram-no do sério. Certa vez, irritado com a presença de um dos garotos que atrapalhava a consulta, Boiadeiro deu-lhe um tapa tão forte que o lançou no outro lado da sala. Também é dado a cantar mulheres em festas, já tendo colocado sua médium em situ- 
ações bastante embaraçosas. Seja como conselheiro e curador, companheiro de farra ou paquerador inconveniente, Boiadeiro participa da vida de muita gente do bairro, com quem já estabeleceu vínculos que aparentemente prescindem da mediação de Ritinha.

Apesar de cada vez mais envolvida com o candomblé, Ritinha insiste em marcar alguma distância. A possessão continua sendo uma experiência problemática, à qual resiste como pode:

Eu não gosto de estar dando santo. Não sei se você já reparou, aí na roça todo mundo dá tudo, todo mundo dá tudo primeiro e você me vê sempre mais recuada. Eu não gosto, é uma coisa que já vem de mim. Essa Oxum minha - eu tenho uma Oxum no meu juntó (segundo orixá pessoal) - para eu dar essa Oxum, eu choro tanto... Parece que tem um negócio que me abafa, eu choro tanto, que eu não quero dar, é uma coisa que eu me prendo pra não dar e, quando eu não agüento mais, é que me pega, que eu choro; acho que eu gasto todas as lágrimas que eu tenho.

Atenta aos sinais corporais que anunciam a vinda de orixás e caboclos, também já desenvolveu algumas estratégias para evitar a possessão: sai para beber água ou, então, começa a pensar em sexo (em "putaria", como ela mesma diz). Infelizmente, explica, sua tática não surte efeito com os caboclos: mais mundanos que os deuses africanos, eles não se inibem com pensamentos pecaminosos. Tem que aceitá-los, entretanto:

Ritinha: Esse caboclo mesmo, se eu pudesse não dava mais ele.

Miriam: Você não gosta dele, Ritinha?

Ritinha: Eu gosto, porque hoje em dia quem está me dando o pão de cada dia dos meus filhos praticamente é ele. Porque às vezes eu estou aqui calada, [a pessoa] não vem com muito [dinheiro] não, mas: "olhe, trouxe aqui esse dinheiro que seu caboclo mandou para comprar uma vela pra ele". Aí eu compro uma vela e sempre sobra da vela, e eu já compro o leite de meus filhos, está entendendo? Então muita coisa eu relevo dele por causa disso.

A história de Ritinha é um bom exemplo do desenvolvimento e da dinâmica das relações com orixás e caboclos, à medida que estas se tornam mais personalizadas e adentram no cotidiano. Ritinha foi levada ao candomblé pela aflição. Lá, seus ataques revelaram-se como um chamado do orixá pedindo a feitura. Ritinha é filha de Obaluaê, orixá da doença e da cura. Usualmente relacionado a doenças de pele - seu corpo é coberto de feridas - Obaluaê é também associado à epilepsia, considerada por alguns 
pais e mães-de-santo como doença de Obaluaê (Caprara 1998). Ao recriar mimeticamente as convulsões que caracterizam a epilepsia, os movimentos espasmódicos de sua dança não só representam esta conexão (confirmando através dela a interpretação do caso de Ritinha), como também oferecem um modelo geral para o desenrolar da aflição (da crise para o movimento controlado, expressão da identidade do orixá).

Os ritos do candomblé, celebrando a descida de orixás e caboclos nos corpos de alguns de seus adeptos, criam um lugar próprio para a experiência da multiplicidade, uma experiência que é essencialmente pública, compartilhada por outros que observam, se divertem e podem mesmo subitamente reverter para essa instância de alteridade. Terreiros circunscrevem o lugar (e especificam as ocasiões) em que os orixás descerão sobre os corpos dos seus filhos humanos. Entretanto, diferente dos deuses africanos, os caboclos abrem caminho para atuar de forma mais direta na vida cotidiana dos fiéis. Como sugerido na história de Ritinha, a presença dessas entidades dificilmente permanece confinada ao espaço institucional do terreiro.

Em estudo sobre a possessão espiritual entre os habitantes da ilha de Mayotte, Lambek (1993) mostrou como os espíritos medeiam as relações dos seus médiuns com outros significativos, introduzindo uma perspectiva nova e autorizada a partir da qual é possível abordar e direcionar essas relações. Podemos observar uma dinâmica semelhante no caso de Ritinha o caboclo permite que ela se situe de modo diferente no contexto da família e da vizinhança, e instala-se como um "terceiro" no circuito dessas relações. Vale notar que os efeitos de tal "triangulação" não dizem respeito apenas ao fortalecimento da posição de Ritinha — que aparentemente o caboclo secunda - mas também a uma mudança na posição dos outros, transformados em mediadores necessários entre a médium e seu espírito, pois Ritinha, ao menos formalmente, depende dos relatos autorizados de vizinhos, parentes e amigos para conhecer e lidar com os desejos e as ações de Boiadeiro. Neste sentido, podemos dizer que os espíritos não só acrescentam novas dimensões às relações sociais, mas também, de uma maneira significativa, instauram o domínio público das interações como arena por excelência, em que tanto os fatos objetivos quanto os desejos, as intenções e os motivos subjetivos dos participantes têm que ser definidos e administrados.

Quando tratamos das conseqüências mais imediatas da possessão na vida cotidiana de Ritinha, percebemos que o caboclo lhe ofereceu um caminho para confrontar emoções problemáticas e lidar com relacionamentos segundo uma perspectiva que, em geral, parece mais vantajosa. O seu desejo de maior independência, de escapar dos constrangimentos de uma vida centrada na casa e nos filhos ganhou forma na liberdade do caboclo. 
Boiadeiro mostra hostilidade aberta às crianças e ingressa livremente no mundo social dos homens: bebe, faz farra, paquera mulheres e anda pelas ruas sem muita preocupação com o espaço doméstico. Isto parece confirmar a idéia, exposta acima, de que a possessão canaliza estados subjetivos, interiores, conferindo-lhes uma forma socialmente legítima. Compensa uma posição marginal, inferior e projeta no espaço público traços discrepantes ou transgressores dos ideais culturais dominantes.

Mas Boiadeiro não é exatamente um rótulo para a expressão de traços de personalidade ou disposições que, sendo incompatíveis com a posição social de Ritinha, tenderiam, não fosse ele, a permanecer escondidos ou reprimidos em sua interioridade. Compreender seu papel no cotidiano de Ritinha exige que nos afastemos da busca de relações externas em direção à identificação de conexões temporais no interior da experiência. Esclareço melhor. Em jogo, aqui estão duas abordagens à questão da temporalidade. Na primeira, há um tempo "achatado" ou "espacializado", em que os desejos e as disposições da médium e os feitos do seu caboclo são tratados como dois fatos "distantes" no tempo, e que se sucedem como causa e efeito: o primeiro provocando ou levando à emergência do segundo que, neste esquema, reflete o que de certa forma já está dado no primeiro. A aplicação deste modelo conduz à conclusão de que no comportamento do caboclo encontramos, em essência, as inclinações da médium. A leitura funcionalista que enfatiza os efeitos "benéficos" ou adaptativos da possessão - na medida em que se constitui em canal para a expressão regulada de tendências transgressoras também se baseia nesse achatamento das relações temporais entre possessão e vida cotidiana; psique do médium e comportamento do espírito.

Romper com essa abordagem requer substituir a noção linear de tempo enquanto mera sucessão por outra que enfatiza as relações de implicação ou elaboração recíproca entre passado e futuro na dinâmica da experiência. Neste modelo, se o passado prefigura ou motiva a eclosão do futuro, cabe ao futuro confirmar e fazer valer o passado em sua retomada. Aqui já não cabe dizer que um comportamento é simples efeito ou expressão do que já estava delineado em seu passado, porque o passado efetivo, que conta na experiência, não é um dado distante no tempo, mas aquilo que ainda vigora no presente do sujeito: é um passado reapropriado e aplicado a novas situações e, neste sentido, não só reefetuado, mas também descoberto e criado. ${ }^{1}$

Esta é precisamente a relação entre o espírito e a subjetividade da médium: se, por um lado, os espíritos representam veículos para a realização de disposições difusas prévias para agir e relacionar-se com outros, por outro, sua incorporação dá lugar a uma dinâmica de elaboração que esclarece, desenvolve e possivelmente transforma essas disposições ao confrontá-las 
com um conjunto novo de situações e possibilidades de agir. Se Boiadeiro reflete o temperamento independente de Ritinha, também é verdade que Ritinha descobre e desenvolve essa imagem independente de si através da alteridade do caboclo. A possessão, enfatizando a multiplicidade, pode liberar o eu singular da responsabilidade e da culpa quanto a certos comportamentos discrepantes da norma, ao mesmo tempo em que oferece um espaço socialmente legitimado para a sua manifestação. Mas talvez mais importante, conduz a uma experimentação ativa de distintos estilos de apresentação de si e relação com os outros. Sendo temporal, esta experimentação é sempre tentativa, e incerta quanto aos seus resultados.

Aqui já cabe a questão: em que medida a possessão por entidades sagradas permite a formação de agentes? Boa parte dos estudos tende a concluir que, ao abrir um espaço de experimentação e distância em relação à ordem social e cultural dominante, a possessão é um meio eficaz para a construção da agência, particularmente entre grupos subalternos. O problema com este tipo de análise é que identifica agência no quadro de uma experiência que enfatiza justamente seu oposto. No candomblé, como em muitas outras religiões que cultivam a incorporação por deuses e espíritos, a pessoa não é tida como responsável por sua ação durante a possessão. Bem ao contrário, tanto no discurso prescritivo geral quanto nas descrições dos membros, é a divindade ou o espírito que detém o controle sobre o corpo da médium. Assim, se concluirmos que a possessão dá força e forma agentes, teremos de reconhecer que para aqueles que são possuídos esta é também uma experiência de sujeição aos ditames de um outro (a entidade), o que nos força a repensar, ou ao menos a abordar com cautela, modelos dominantes de agência e poder.

Ao tratar desta questão, alguns trabalhos recentes têm chamado a atenção para a necessidade de se reconhecer agência aos espíritos, conforme o fazem os próprios sujeitos que com eles interagem. Ao (con)fundirem a agência das entidades com a agência de seus médiuns, muitos dos modelos analíticos vigentes não apenas demonstram um realismo ingênuo, como se revelam incapazes de dar conta das complexas relações entre médiuns, entidades e outros humanos - as quais freqüentemente incluem situações em que as entidades impõem fortes restrições ou exigem de suas médiuns, em troca da aliança, compensações bastante onerosas. Conforme observa Birman,

[...] dizer que as mulheres médiuns ganham poder por intermédio da prática da possessão é, pois, uma parte da história. A outra parte, não menos valorizada por elas, diz respeito à idéia que fazem dos seus próprios limites: elas não podem tudo porque o controle sobre estes outros agentes a seu favor é também limitado e submetido a uma lógica que lhes escapa (Birman 2005:411). 
Igualmente relevante nessa discussão é a própria experiência vivida pelos sujeitos quando tomados por entidades e espíritos, experiência cujos contornos são definidos não tanto pela atividade, mas por certa passividade ou perda temporária da agência (ver Kramer 1993; Lambek 1993 e Keller 2002). Ao escrever sobre a prática religiosa/ritual em geral, Miyazaki (2000) sugere que do ponto de vista dos praticantes sua força reside justamente no movimento que ela instaura de suspensão e posterior recuperação da agência. ${ }^{2}$ Segundo o autor, a antropologia da religião freqüentemente negligencia a importância que essa experiência de "desagenciamento" assume para os sujeitos.

O cultivo de atitudes como passividade e docilidade na construção de relações com as entidades sagradas pode, além disso, estar intimamente relacionado aos modos pelos quais as disciplinas religiosas formam agentes. Se definirmos agência como capacidade para agir, não é difícil perceber que o exercício da docilidade é parte importante do processo pelo qual são aprendidas habilidades necessárias à sua construção. Docilidade, argumenta Mahmood, "implica a maleabilidade que é requerida de alguém para ser instruído em uma técnica ou conhecimento particular" (Mahmood 2001:210); neste sentido, não é mera sujeição (aquilo que tendemos a pensar como a antítese da agência), mas dimensão formativa da agência.

Apesar das diferenças, estes argumentos revelam a fragilidade dos modelos que operam uma relação não mediada e não problemática entre possessão, articulação da agência e fortalecimento do sujeito. Tanto a autonomia relativa dos espíritos, enquanto agentes no jogo interativo, quanto a perda relativa da autonomia dos médiuns, quando possuídos, têm implicações sérias sobre as modalidades de agência articuladas através da possessão. É bem verdade ser possível fazer frente a essa crítica postulando-se uma diferença essencial entre discurso e prática, entre o discurso das médiuns que estrategicamente enfatiza a agência das entidades e minimiza a sua própria - e a sua prática efetiva (é bom lembrar, tal qual observada e articulada discursivamente pelo investigador) — em que as médiuns se revelam como agentes plenos, o seu discurso servindo apenas para legitimar demandas dirigidas ao poder sagrado.

Mas a não ser que estejamos satisfeitos em descartar as descrições dos atores como meras racionalizações sem conseqüências sociológicas de peso, nossos modelos interpretativos da possessão como prática social devem levar em conta a agência das entidades, suas conseqüências no jogo social e a experiência de passividade dos médiuns: os modos de entrega e submissão, assim como as estratégias de resistência. Estes modos fazem parte de um saber compartilhado (e prescrito) na religião, explicitamente cultivados 
pelos sujeitos, ou ocasionalmente vividos nas relações com as entidades (vale notar, por exemplo, a aproximação, feita por Ritinha, entre a entrega e a completude no ato sexual e na incorporação do caboclo).

Apenas ao considerarmos essas experiências, torna-se possível entender o estabelecimento da agência através da possessão, evitando-se as alternativas pobres de tratá-la quer como perda total e sem sentido do controle, quer como manipulação estratégica de um contexto normativo. $\mathrm{O}$ sujeito ativo que confronta a situação, infundido pelo poder das entidades que o possuem, é também aquele que em certa medida vivencia a suspensão da sua agência durante a possessão e se submete à vontade das entidades e, no caso dos que ingressam na instituição religiosa, à estrutura hierárquica do terreiro e à autoridade da mãe-de-santo.

A história de Ritinha coloca-nos também diante de outro ponto importante que está no cerne da teoria da prática: a questão do significado. Trata-se não apenas de precisar o sentido da experiência, mas de dar conta de sua construção, em uma trajetória que se inicia com a aflição e culmina com o estabelecimento de vínculos com as entidades via possessão. Passo agora para um segundo caso, cujo desenrolar acompanhei de perto.

\section{Possessão, corporeidade e sentido}

Curió é um rapaz negro de 24 anos. Mora só em um quarto alugado e trabalha como pedreiro. Estava envolvido numa obra no terreiro de mãe Jandira quando uma série de eventos conduziu-o em poucos meses à feitura (iniciação). Vinha sofrendo de fortes dores de cabeça, sentia que estava definhando. Procurou uma rezadeira conhecida, mas não percebeu mudança em sua condição. Consultou-se então com Jandira, que recomendou uma limpeza; seguiu as prescrições e melhorou. Mas não ficou bom de todo. Algum tempo depois, um amigo aconselhou-o a conversar de novo com a mãe-de-santo: em breve haveria um bori para um grupo de quatro, quem sabe Curió não se juntava a eles, o que certamente diminuiria os custos.

O bori é o rito de dar de comer à cabeça ou ori, que no candomblé é sagrada, cultuada como lócus da individualidade. Visa fortalecer o ori, trazendo equilíbrio para o indivíduo e firmando sua cabeça para receber o orixá (antecede assim a qualquer processo de feitura). Envolve uma seqüência de oferendas ao ori, incluindo a noz de cola, obi, seu alimento por excelência.

Curió ficou relutante em face do conselho do amigo; embora fosse ao terreiro todos os dias, ele assim fazia como trabalhador e não como adepto ou cliente, e não costumava freqüentar as festas e as sessões de caboclo 
que ocorriam à noite. As poucas ocasiões em que o fizera não foram muito felizes. Certa vez, ao receber um abraço do caboclo da mãe-de-santo, Pai Caitumba, sentiu-se tonto:

Aí eu senti o pé... parecendo que os pés não estavam no chão. Eu senti, parecendo que estava levantando; aí me senti tonto. E aí peguei, sentei, relaxei um pouquinho. E outras vezes, eu sentado, eu sentia... parecia que meu ombro ia, ele ficava bulindo assim, eu sentado ficava aqui, me arrepiava todo e o ombro começava a tremer. Mas aí eu disfarçava, levantava, saía.

Ao jogar os búzios para Curió, Jandira reforçou a necessidade do bori. Finalmente convencido, o rapaz submeteu-se ao rito.

No terreiro, o bori é sempre antecedido por um ebó (oferenda) para Iemanjá, orixá protetora do ori, e é feito na praia. De volta ao terreiro, os noviços tomam banho de folha, vestem-se de branco e aguardam o início do rito, que ocorre à noite. Sentados em tamboretes ou numa esteira, têm suas cabeças lavadas. Uma seqüência de alimentos é oferecida à cabeça e recolhida em uma bacia que cada um segura no colo. Milho branco cozido, sangue do pombo sacrificado e fatias de obi são colocados na cabeça e mantidos seguros por um ojá (lenço branco) amarrado em sua volta como um turbante. Findo o rito, os noviços deitam envolvidos em cobertas; devem passar a noite e a maior parte do dia seguinte descansando, também eles, se nutrindo com alimentos relacionados ao ori - frutas, na maioria. No final da tarde, a mãe-de-santo vem suspender o rito. Os noviços tomam banho e são instruídos a seguir um conjunto de prescrições comportamentais e alimentares que compõem o resguardo. Curió contou assim sua experiência:

Nesse dia do bori, eu estava alegre, muito alegre, né? Parecendo que ia acontecer uma coisa boa em minha vida, quer dizer, aconteceu, né? [...] Então aí fez o ebó primeiro, aí fui à praia. Então teve o ebó de praia. Lá eu senti, quer dizer, eu não sei, só vi na hora dona Tânia me acordando, me chamando, que eu estava de joelhos, ela me chamando "Curió", "Curió". Eu sei que eu vi pouca coisa, só na hora quando ajoelhei; aí começou a cantar e a menina virou (possuída) do meu lado, e depois eu não vi mais nada... Nem vi, nem ouvi. Só vi quando ela estava me chamando, me sacudindo, pegando no ombro e me balançando. Que eu não sabia que era rodante (pessoa que pode ser possuída pelos orixás). Aí eu me levantei. Aí quando eu vim pra cá, que chegou na hora, já tinha tomado banho. Aí sentei pro bori, assim... Quando começou o bori, em menos de cinco minutos não vi mais nada, só ouvi quando começou a cantar, começou a cantar... Aí não vi mais nada. Aí eu senti o meu corpo me balançar como se 
tivesse alguém pegando meu ombro, os dois ombros e sacudisse. [...] Aí, no outro dia, eu lembro que já acordei com a mesa de frutas. Já estavam. Aí... relaxei, [estava] bem, bem leve o corpo, me sentindo outra pessoa, como a pessoa que vai pra uma mesa de cirurgia e, quando volta, volta sem nada, sem sentir dor nenhuma. Voltei bem, acordei bem, mas quando chegou assim o espaço de uma hora de relógio que eu estava de manhã acordado, aí começou o santo a me pegar de novo. Aí não via mais nada, sentia meu ombro sacudir mesmo. Sentia mesmo, que isso aqui ficava me doendo, como se eu tivesse feito alguma coisa de errado e alguém pegava e me sacudia mesmo, me rumava pelas paredes. Eu sentia isso aqui, o ombro, o abdômen, o tórax, tudo doendo, pescoço... Aí a mãe-de-santo vinha. Eu lembro que quando acordava, estava nos pés dela assim. Aí demorava assim na base de dez ou vinte minutos, e de novo. Aí eu sei que acordava chorando, começava a chorar, ficava com medo, começava a chorar. Aí ela (a mãe-de-santo) ia explicando... Quando ela saía, que voltava, eu já estava ruim de novo. Às vezes eu ficava acordado assim, acordado, mas sentindo meu peito sacudir. E o ombro ir pra trás e pra frente. Forte mesmo, e aí não via mais nada de novo, era assim. Foi (assim) até de tardezinha, até na hora de suspender o bori. Eu me sentindo mal. [...] Estava mal mesmo, o ombro, tudo doendo, parecendo que eu tinha pego um peso, peso enorme mesmo, de mil quilos. Ficava com os braços moles. E chorava. Aí, quando levantou o bori, não senti mais nada. É, passou assim... Aí no outro dia eu comecei, como se fosse, vamos supor, soluçando, como se eu estivesse soluçando.

Estes acontecimentos dramáticos desencadearam em Curió uma memória há muito esquecida. Conforme contou, vinha de uma família que estivera envolvida com candomblé: sua mãe "tinha santo" e, ao que parece, freqüentava um terreiro da localidade. Curió acreditava que tinha herdado dela sua ligação com os orixás. Sua madrasta, também freqüentadora de casas de candomblé, costumava levá-lo, criança ainda, para as festas. Nessas ocasiões, invariavelmente passava mal, ficava tonto e perdia os sentidos. Também quando sentava no chão para comer costumava cair para trás, debatendo-se, e acordava à noite cantando cantigas de orixá. Preocupado com a situação, o pai decidiu consultar uma mãe-de-santo local, que logo confirmou suas suspeitas: a criança precisava ser feita no candomblé. Por querer a todo custo evitar que Curió trilhasse este destino, ele então acertou com a especialista religiosa para que o orixá do menino fosse suspenso mediante procedimentos rituais, dando um fim às incorporações. Segundo Jandira, esse tipo de medida era muito usado nas casas de candomblé mais antigas; o mesmo fora feito com ela quando criança. Mas tratava-se de uma solução temporária ou de um simples retardamento que, ao final, só fazia 
piorar as coisas, pois quando o problema voltava - o que mais cedo ou mais tarde acabava acontecendo - era muito mais grave. O caso de Curió bem confirmava suas palavras.

Jandira avaliou a situação de Curió da seguinte forma: ele deu um bori para aliviar as dores na cabeça, só que, quando melhorou a cabeça, Ogum começou a passar. Ficou pegando Curió, mas em um transe incompleto. Depois Ogum deu passagem para Exu, e aí as coisas pioraram. Nos dias que se seguiram ao bori, Curió passava mal quando possuído, via-se uma protuberância crescer em sua têmpora, como se inchasse. Ele chorava em desespero. Jandira já estava se sentido incompetente, não sabia mais o que fazer. Ao perceber que o estado de Curió se agravava, levou-o, desesperada, até a casa de Exu, pequeno quarto situado na parte externa da casa, onde estão assentados os exus do terreiro, e lá falou de forma dura com a entidade responsável pelo estado do rapaz: pediu-lhe que esperasse, que ele iria receber o que lhe era devido, mas que por enquanto deixasse em paz seu filho Curió. Falou tão alto e em um tom tão ríspido que muitos dos que estavam no terreiro acorreram de pronto, pensando tratar-se de uma briga. Deixou Curió na casa de Exu e seguiu para sua casa. No caminho, ela mesma foi tomada pelo exu Pata de Ouro que, segundo me explicou mais tarde, veio em resposta ao seu desespero. Pata de Ouro é um perigoso exu de rua que já levou vida de criminoso. Costuma resolver muitos problemas para Jandira e, como qualquer outro exu, atende aos pedidos daqueles que sabem agradá-lo.

Curió teve sua rotina transtornada: não conseguia trabalhar. Sentia que estava "irradiado", cercado pela presença do orixá que assumia o comando do seu corpo. Temeroso de sair à rua, foi ficando na casa de Jandira. Diversas vezes pude vê-lo "soluçando": ficava quieto em algum canto, mas o menor ruído (uma campainha, um grito da rua) parecia provocar-lhe espasmos no corpo todo. O povo da casa acorria, algumas das filhas-de-santo de Jandira pousavam a mão no seu ombro e faziam-lhe uma leve massagem nas costas. Aos poucos ele se recuperava. Apesar do cuidado que demonstravam ter com ele, também riam por trás, comparando Curió a uma jovem grávida que, enjoada, constantemente provocava vômito ("engulhando"). Desesperado, Curió abraçava, aos prantos, a mãe-de-santo, pedindo ajuda.

Assim que conseguiu mobilizar entre os membros do terreiro os recursos mínimos para a feitura, Jandira recolheu Curió. Aproximadamente duas semanas antes fora feita a matança para Exu, oferenda animal a este orixá que deve iniciar o processo de iniciação. Nesse dia, o banco dos atabaques foi colocado do lado de fora do barracão, próximo à casa de Exu. As pessoas — todos membros do terreiro, apenas dois ou três visitantes habituais - 
aglomeraram-se de ambos os lados. Começaram a tocar e a cantar para Exu e trouxeram o bode que seria oferecido ao orixá. Curió estava de pé, em um canto, próximo a duas equedes. ${ }^{3}$ Não era o centro das atenções. Logo chegaram alguns exus andando com os pés tortos e os dedos rijos, os rostos contorcidos. As padilhas, exus femininos, vinham faceiras, risos estridentes, pedindo cigarro e dando cantada nos homens. Quando olhei para Curió, seu corpo estava pendendo de um lado para o outro. Os espasmos foram se tornando cada vez mais violentos e descontrolados; em um dado momento, tive a impressão de que ele acabaria batendo contra a parede próxima. Uma das equedes pousou com firmeza a mão em seu ombro e permaneceu nessa posição até que os movimentos foram diminuindo de força e intensidade e ganhando um ritmo compassado, pendular.

Ao tentar, no dia seguinte, descrever essa experiência (ao menos durante o tempo em que ainda estivera parcialmente acordado), Curió contou:

Na hora que foi dar a comida de Exu, eu me lembro que a menina me chamou, eu fiquei assim, encostado. Na base de um minuto, eu senti meu corpo crescer e aí não vi mais nada. $\mathrm{O}$ meu pescoço, minha cabeça balançando muito... eu não sei, alguém pegou no meu cabelo, começou a sacudir, né? É [senti] isso aqui do ombro crescer e os pés ficarem grandes e o meu corpo - parecia que eu me levantava, que me levantavam assim, me colocavam lá em cima - ficava todo pesado. E não via mais nada, quer dizer, eu não vi mais nada, só vi na hora que acordei também; estava no chão, ajoelhado, o pessoal me segurando. Aí eu só lembro quando meu corpo, né? quando senti meu corpo crescer, minha respiração mudar, e eu fui cochilando devagarzinho, como se alguma pessoa [estivesse] me sacudindo pra dormir. E eu não vi mais nada, só quando eu acordei. [...] Quer dizer, é como se uma criança estivesse numa rede, e alguém balançando muito... Vai pra lá, vai pá cá, como se estivesse numa gangorra. É isso, quer dizer, nem é ruim, nem é bom, né? Porque é uma coisa que move muito com o corpo; agora, depois que a pessoa dorme, é bom. Quando acorda está livre.

Curió engordou bastante durante o período em que ficou recolhido. Seu Ogum dançou potente no dia da saída. Ainda ficou muitas semanas na casa de Mãe Jandira, e foi retomando aos poucos a rotina de trabalho.

A trajetória de Curió é, em vários aspectos, uma trajetória típica do candomblé, na qual a relação com o orixá se revela através da aflição e a cura está atrelada ao estabelecimento de relações duradoras com a divindade via iniciação.

No âmbito da literatura antropológica, muitas interpretações têm sido oferecidas ao papel da possessão no tratamento. Uma das mais influentes 
é a idéia de que a possessão pode ser vista como um idioma para a articulação da experiência subjetiva. Nas palavras de Crapanzano, o processo de articulação

[...] é mais que uma representação passiva do evento; é em essência a criação do evento. Separa o evento do fluxo da experiência, daquilo que Alfred North Withhead viu como "um correr sem fim e sem sentido de material". Provê estrutura ao evento, precipitando assim seu contexto, relaciona-o a outros eventos construídos de forma semelhante e avalia o evento de acordo com linhas idiossincráticas e culturalmente padronizadas. Uma vez que a experiência é articulada; uma vez que é transformada em evento, é jogada em um mundo de sentido e pode assim prover bases para a ação (Crapanzano 1977:10).

Esta é certamente uma contribuição-chave para o estudo da possessão: enfatizando os elos de significado entre possessão e experiência de sofrimento, escapa ao reducionismo de muitas abordagens ao tema. Reter o vigor da noção de articulação exige, entretanto, problematizar e desenvolver o conceito de significado que está atrelado a ela.

Tal qual formulado por Crapanzano, a produção de sentido envolve uma ruptura no fluxo da experiência: o significado emerge de um ato de distanciamento em relação ao que é simplesmente vivido - tomado como mero fluxo desprovido de sentido - que permite construir objetos e eventos. Central nesta concepção é o postulado de uma descontinuidade entre o vivido e o pensado, a experiência e sua representação. Não é muito difícil perceber a afinidade entre esta idéia e a assertiva de que nossa inserção corporal no mundo é um fluxo sem fim de sensações e impressões que só adquirem sentido quando articuladas através da linguagem: ao hiato entre experiência e significado ou percepção e linguagem corresponde freqüentemente uma separação entre corpo e consciência (ou mente) na teoria social. Nessa perspectiva, a possessão é vista como se integrasse um processo social de imposição de sentido a experiências que, estando fechadas na subjetividade (ou nas relações mudas entre o corpo e seu entorno), precisam ser lançadas no mundo do significado para serem administradas.

Nas ciências sociais contemporâneas, podemos discernir um movimento teórico importante de crítica e superação desses dualismos que tem repercussões importantes sobre o conceito de significado. No estudo da possessão espiritual esta crítica tem marcado presença, seja explícita ou implicitamente, nos escritos do antropólogo norte-americano Paul Stoller. Segundo Stoller (1997), o emprego recorrente de analogias retiradas do domínio da produção textual (possessão como texto, idioma, metalinguagem etc.), ou mesmo 
de conceitos de viés mentalista, como o já consagrado "estado alterado de consciência", tem gerado uma cegueira analítica para a dimensão encarnada (embodied) fundamental da possessão. Assim orientados, os estudos pecam por não considerar devidamente a "centralidade do corpo sentiente na possessão" (Stoller 1997:55), um corpo "culturalmente consumido por um mundo repleto de forças, cheiros, texturas, visões, sons e gostos, todas elas agindo como gatilhos para memórias culturais" (Stoller 1997:54).

Ao propor uma descrição da possessão pelo viés do corpo e da percepção, o argumento de Stoller levanta uma série de pontos importantes cujos fundamentos teóricos gostaria de examinar. Em primeiro lugar, parece assentar-se sobre um entendimento da percepção - mobilização de um corpo sentiente por um mundo sensível - enquanto, ela mesma, experiência de sentido, e não contato pré-cultural ou pré-significativo com o mundo. Esta experiência, além do mais, é vista como se guardasse uma relação fundamental com o passado - faz eclodir uma memória cultural - para o qual está, portanto, aberta. Como estes pontos, pelo menos em parte, encontram inspiração na fenomenologia e, mais particularmente, na fenomenologia de Merleau-Ponty, vou me deter em alguns aspectos do pensamento deste filósofo que me parecem mais diretamente relevantes para a nossa discussão.

Na Fenomenologia da percepção (1994), Merleau-Ponty busca empreender uma redescrição da experiência perceptiva que supere os impasses das teorias rivais do empirismo e do intelectualismo (a primeira reduzindo a experiência a uma recepção passiva de estímulos; a outra, subordinandoa à construção intelectual de um sentido imposto a impressões disformes). Influenciado pela Gestalt, observa que o sujeito da percepção não é confrontado com uma corrente caótica de sensações que precisa organizar através de um ato de cognição, mas com um campo organizado de figura e fundo, no qual ele mesmo, enquanto corpo, está já implicado ou posicionado.

Há aqui uma redefinição importante do conceito de sentido. Se a percepção já é imbuída de sentido (ou configuração), o sentido que nela se esboça não é uma representação intelectual do objeto visado, mas certo modo de relação (Merleau-Ponty usa os termos diálogo e comunhão) entre o corpo e o seu entorno. Através dele a atividade exploratória do corpo descortina novos perfis dos objetos, sendo ela mesma uma resposta ao apelo dessas configurações sensíveis, sintonizando-se ou ajustando-se a elas. A experiência perceptiva é tanto uma exploração do mundo circundante, quanto uma resposta às suas solicitações, aos modos em que as coisas, os outros e os lugares apelam aos sentidos, conduzem a certas maneiras de engajamento corporal (relaxamento ou atividade, por exemplo), dirigem a atenção e o movimento. 
Este argumento embasa uma crítica à noção de sentido como forma imposta sobre conteúdo - crítica que é particularmente relevante para a nossa discussão. Em Fenomenologia da percepção, Merleau-Ponty procura evitar uma concepção do sentido como transcendente à experiência - a imposição de uma forma que, em última instância, dissolve a multiplicidade dos conteúdos - e uma definição que o toma como puramente imanente à experiência - a mera soma de conteúdos individuais diversos. É precisamente seu entendimento do sentido como inseparável do tempo que lhe permite escapar da alternativa. ${ }^{4}$ Se o sentido não é nem uma forma atemporal que paira sobre a experiência, nem o resultado arbitrário de uma série de experiências singulares, é porque toda a experiência está sempre aberta ao passado e ao futuro, já que (minhas) ações pedem desdobramentos que serão realizados e retomados por outros. Isto porque, enquanto inseridos numa tradição, somos mobilizados por uma interrogação do passado que nos conduz a direções que, embora formem um padrão, não estão imunes à contingência dos eventos. O sentido, escreve Merleau-Ponty, é instituído (ao invés de constituído); é um estilo que emerge através de sucessivas apropriações de modos herdados de agir, interagir e sentir. Na imagem eloqüente do autor, o sentido é "convite para uma seqüência" (Merleau-Ponty 1968a).

Voltemos então a Curió e vejamos que implicações essa discussão mais geral pode ter na interpretação de sua trajetória. Em primeiro lugar, conduz ao abandono da noção de que a aflição é essencialmente uma experiência incoativa, fechada no corpo ou na interioridade do sujeito. Conforme vimos, o sofrimento de Curió se dá também em uma série de encontros e interações com outros, é recortado por conversas, opiniões e conflitos, e já traz uma compreensão (difusa) de sua situação, um senso do seu peso ou gravidade. As relações que Curió desenvolve com Jandira e com os membros do terreiro adicionam novas camadas de sentido a esta experiência, articulando (esclarecendo, desenvolvendo, especificando) algumas das possibilidades para as quais ela está aberta enquanto experiência situada em uma história pessoal ou, em outro nível ainda, em uma tradição compartilhada. Ao revelar os elos entre sofrimento e chamado divino, a possessão de Curió não é um significado que se sobrepõe a uma vivência incomunicável; é antes parte daquilo que a aflição vem a ser à medida que ele se envolve no candomblé, ajustando-se a esse novo contexto e aos outros (pessoas e deuses) que o habitam.

Conforme notamos acima, este "ajuste" é também e fundamentalmente um modo de engajamento corporal. Entender a possessão como prática corporificada, escreve Stoller, é entender os modos pelos quais o corpo é mobilizado ao longo de uma seqüência de operações e cuidados em que se 
justapõem e alternam variados meios; é dar conta de sua participação gradativa em contextos carregados de som, cores, cheiros e sabores (Stoller 1997). A narrativa de Curió está carregada de exemplos de como o engajamento no candomblé se dá através de práticas, relações e experiências que implicam um despertar e um desenvolver de sensibilidades. O que está em jogo nessa experiência não é nem uma reação mecânica a estímulos, nem a atividade interpretadora de uma consciência: é o advento gradual de um modo de se relacionar, de deixar-se tocar e atentar corporalmente para uma situação.

Curió inicia sua trajetória com uma queixa genérica - fraqueza, falta de ânimo, dores de cabeça. Depois de uma visita frustrada a uma rezadora, segue o conselho de um amigo e aproxima-se do candomblé. Em uma sessão na casa de Jandira quase perde os sentidos após o abraço recebido do caboclo. Dois pontos importantes podem ser levantados a partir de um exame desta seqüência de eventos. É possível afirmar, em primeiro lugar, que a possessão (ainda indefinida) aparece, já aí, como um modo de relação ao contexto (para aqueles presentes à cena, é uma resposta direta ao gesto do caboclo, um desdobramento "natural" deste gesto); em segundo, conduz a uma redefinição mesma do que conta como contexto, ou melhor, do que deverá ser objeto direto de medidas e intervenções (é a possível presença de um espírito que define agora o contexto em que os envolvidos devem atuar).

A segunda vez em que Curió é afligido pelas entidades, ele já é participante direto do rito. Isto ocorre durante a fase inicial do bori, na praia, quando oferendas são derramadas sobre as cabeças dos noviços. Esta é uma situação que, no candomblé, tipicamente conduz à possessão dos rodantes, daqueles cujos corpos são veículos dos orixás. Curió vê alguns de seus irmãos de bori virarem no santo. No entanto, de uma posição inicial de observador, também ele é envolvido pela situação, revertendo para um estado de pura passividade ("depois não vi mais nada"). Como no evento anterior, o contexto de sua aflição é redefinido pelos acontecimentos do bori, e a experiência difusa de sofrimento é ela mesma especificada ou articulada através do despertar de novas sensibilidades durante o rito. As medidas "terapêuticas" acionadas no terreiro conduzem gradativamente a uma maior elaboração dessa situação inicial, contribuindo mais e mais para defini-la enquanto apelo do orixá. Envolvem uma sensibilização do corpo para contextos de sons, cores, cheiros, pessoas e objetos relacionados às entidades sagradas, habilitando-o para responder a tais contextos e a operar neles distinções cada vez mais sutis.

Podemos dizer que no caso de Curió (assim como na história de Ritinha) a aflição é articulada (sintetizada, especificada, transformada) inicialmente como movimento rítmico (os "soluços" e os espasmos compassados, a 
sensação de estar sendo jogado de um lado para outro e depois balançado numa rede). O ritmo compele, reorganiza tanto o corpo quanto o lugar, em termos de sua própria dinâmica temporal. O corpo, cedendo ao ritmo, parece inteiramente determinado pelas solicitações do lugar (que nos ritos vêm da música, mas também de cores, formas, sons e texturas que compõem o espaço do evento). O lugar, desdobrando-se e redefinindo-se através do movimento rítmico, mostra-se como um prolongamento mesmo da instância e-motiva do corpo. Na história de Curió, essa natureza dual do ritmo é expressa através de imagens contrastantes: enquanto as experiências de ser erguido e jogado e depois balançado numa rede sugerem uma interferência que vem de fora, os espasmos e os "soluços" insinuam uma força ou um movimento que cresce desde dentro.

Tambiah (1981:114), recuperando elementos da reflexão de RadcliffeBrown sobre a dança, nota justamente que o ritmo "age sobre o indivíduo tanto de fora (como performance coletiva) quanto de dentro (uma vez que o impulso para ceder vem do seu próprio organismo)". Similarmente, Slavin (2003) argumenta que o ritmo atravessa as fronteiras entre o interior e o exterior; entre o corpo e a mente, de um lado, e o "social" ou o fazer coletivo, do outro. Na experiência da longa caminhada a Santiago de Compostela estudada pelo autor, os romeiros contam com o ritmo enquanto mecanismo de centramento do eu durante a jornada, uma forma de sintonia com o entorno que combina submissão e controle (Slavin 2003:10).

No candomblé, diferentes modulações de ritmo marcam a presença das entidades e ajudam os corpos dos fiéis a se ajustarem a tal presença. Essa dimensão "organizadora" do ritmo é chave para compreendermos a ação da equede durante a comida de Exu. Ao pressionar a mão contra o ombro de Curió, ela orienta o movimento do seu corpo, permitindo que os espasmos violentos de que ele é tomado dêem lugar a um ritmo compassado. Ao fazê-lo, abre caminho para a construção de uma relação mais duradoura e rotineira com o orixá - em que a surpresa, a violência e a dor são substituídas por constância e certeza do ritmo. As histórias de Curió e Ritinha parecem indicar que no candomblé o ritmo funciona como base inicial a partir da qual novas sínteses corporais podem ser desenvolvidas ao longo da carreira religiosa, e possivelmente acionadas na lida com a aflição.

A título de conclusão provisória sugiro, então, que é preciso esclarecer a assertiva de que a possessão articula a experiência de aflição, infundindolhe um significado. Articulação não é passagem da pura ausência de sentido para sua efetiva criação; descreve antes um percurso de elaboração do sentido em que criação e reaquisição, descoberta e repetição estão sempre associadas, como dois lados de uma mesma moeda. 
Mas ao tratar da possessão e sua conexão (de sentido) com a aflição, ainda não consideramos um elemento central da história de Curió. Como ele mesmo ressalta, sua trajetória remete a eventos passados que envolvem também membros do seu círculo familiar. As experiências perturbadoras que ele vivencia antes da iniciação adquirem sentido à luz de um passado coletivo que a possessão retoma e reefetiva. Gostaria de examinar esta questão voltando-me agora para uma última história - a de Jandira, mãede-santo de Curió.

\section{Possessão e recuperação do passado}

Mãe Jandira foi iniciada há mais de trinta anos. Tem hoje pouco mais de sessenta; é uma mulher negra, ativa, de temperamento forte, mas também paciente e extremamente habilidosa em resolver problemas sem transformá-los em conflitos abertos. Seu terreiro está localizado em um bairro socialmente misto, em que habitações de classe média dão lugar a invasões populares à medida que o bairro se afasta da orla. A maioria dos adeptos do seu candomblé vem das áreas mais pobres da cidade. Muita gente reside no terreiro, além dos filhos e dos netos de Jandira (eles mesmos já ligados a ela pelo parentesco religioso); alguns são residentes permanentes, outros moradores temporários que lá encontram um refúgio para tempos difíceis ou que foram ficando sob a proteção da mãe-de-santo com o término do processo de iniciação.

Jandira foi criada na Liberdade, bairro antigo de classe trabalhadora. Não freqüentou o candomblé durante a infância, embora seu pai mantivesse em casa um pequeno altar onde guardava os assentamentos do seu orixá. Segundo conta, ele era descendente de africanos e também um abiku, ${ }^{5}$ pessoa cujos vínculos com os deuses são estabelecidos de nascença e, portanto, não precisa passar por processo formal de iniciação. Aos sete anos, Jandira teve seu primeiro contato com os orixás - não com Logunedé, a quem foi posteriormente consagrada - mas com Obaluaê. Entretanto, tendo decidido que não queria vê-la envolvida no candomblé, seu pai utilizou seus conhecimentos religiosos para "suspender o santo" da menina (semelhante ao que foi feito no caso de Curió).

Eu nasci dentro da Liberdade, pra começar a história, que a Liberdade você sabe como é. Nasci na Liberdade, fui filha única, entendeu? Fui criada de modo muito rígido, porque era danadinha, essa coisa de criança mesmo... Com sete anos, Obaluaê me pegou; eu tinha 7 anos de idade, mas meu pai fazia parte de 
candomblé, mas na parte do abiku. Ele, então, dizia que sabia suspender santo, que não me queria no meio do candomblé, nesse movimento, então disse que suspendeu. Realmente, eu nunca mais... Eu estava deitada e, quando eu vi, foi um velhinho vindo com duas muletas, isso era coisa da minha imaginação, não sei se é verdade. Então ele vinha, chegava junto de mim e batia com aquelas muletinhas. Como ele batia com as muletas, eu amanheci toda de bexiga, amanheci coberta de bexiga.... Com 7 anos de idade, foi quando Obaluaê me pegou, talvez fosse pra poder melhorar minha doença, porque ele é o dono da doença, é o médico, né, da doença. Passou, cresci, fui estudar, depois fiquei mocinha, num queria, num liguei pra essas coisas...

Muitos anos depois, já casada e mãe de família, Jandira restabeleceu contato com os orixás para pedir por seu marido, que estava enfrentando sérios problemas no trabalho. Freqüentou assiduamente as atividades de um terreiro onde fazia oferendas regulares aos deuses. Mas os orixás queriam mais, e a eclosão de uma doença finalmente a conduziu à feitura. Jandira passou seis meses no terreiro, três dos quais no roncó (quarto onde são recolhidos os noviços durante a iniciação), junto com outras nove mulheres.

Jandira é filha de Logunedé - fato que só descobriu quando já estava prestes a fazer o santo - e tem Iansã como juntó (segundo orixá pessoal). A possessão por estas entidades guarda uma qualidade sensível própria a cada uma delas que Jandira já aprendeu a distinguir (aprendizado que sinaliza provavelmente uma maior consolidação das relações com os orixás, fruto da carreira religiosa e, é claro, do próprio tempo de convivência):

Na realidade, o meu orixá, Logunedé, se eu estiver aqui sentada... eu estou parecendo que eu vou falecer, parecendo que eu vou desmaiar, desmaiar, desmaiar, vou sentindo aquilo, vou sentindo aquilo assim, parecendo que eu vou... Aí pronto, eu já não vejo mais nada. [...] Iansã, quando ela me apanha, eu não sinto diferença; eu sinto diferença depois que ela vai. Eu sinto um fogo, aqui no rosto fica em tempo de sair... uma quentura horrível, entendeu? Mas se ela sair e passar o erê, ${ }^{6}$ você não sente nada. É por isso que tem o erê, o santo saiu, passou o erê, você não sente nada, mas se o santo sair sem passar o erê... Quando a gente vai ficando mais velho no santo, o erê já não vem. [...] É, porque fica chato também a gente, mãe-de-santo, com erê. Mas o erê segura muito a onda que a gente não agüenta.

Estava já satisfeita na posição de filha-de-santo dedicada, quando chegou o momento de receber o decá, rito de confirmação de sua futura posição de sacerdotisa. Embora este destino tivesse sido proclamado há bastante 
tempo pelo seu pai-de-santo, ela recusava-se a aceitar o cargo. Novamente sobreveio-lhe a doença: desta feita uma experiência que descreve como enlouquecimento. Em uma consulta aos búzios, Logunedé respondeu e prometeu que ela recuperaria a saúde se assumisse a obrigação que vinha evitando a todo custo. Jandira seguiu as prescrições do orixá, recuperou-se, mas seguiu impedida de levar adiante a promessa de se estabelecer como mãe-de-santo, desta vez em virtude de limitações financeiras para abrir um terreiro. A solução veio afinal através do seu caboclo, Pai Caitumba, que aconselhou seu marido a requerer aposentadoria por invalidez. Com o dinheiro da aposentadoria, compraram o terreno onde hoje está o terreiro. Lá estão assentados não só seus orixás pessoais (e os de seus filhos-de-santo), como também o orixá de seu pai, de quem lhe coube cuidar.

Caitumba interveio junto ao marido de Jandira a favor do seu projeto de tornar-se uma mãe-de-santo. Como o Boiadeiro de Ritinha, desempenha papel importante de mediador em várias das relações que Jandira mantém no terreiro, com clientes e filhos-de-santo. Durante as cerimônias que são dedicadas a ele, Caitumba oferece conselhos, prescreve remédios e faz sacudimento nos clientes, que se enfileiram para obter uma consulta individual. Também é ele quem dá voz a queixas contra os filhos-de-santo de Jandira e impõe demandas a eles, favorecendo os interesses da médium e, ao mesmo tempo, protegendo-a de conflitos diretos com seus subordinados - o que poderia minar as boas relações no terreiro. Registrei um desses eventos em meu diário de campo:

Semana passada, uma filha-de-santo de Ogum disse para as irmãs que ia sair do terreiro levando seu santo (os assentamentos) com ela. As outras contaram à mãe-de-santo. Jandira fez que não deu importância. Ontem, durante a sessão, pai Caitumba convocou seus filhos para um sermão. Disse que quem estava na roça devia estar de coração, nunca contra a vontade, se achava que devia sair, que fosse, pegasse suas coisas e procurasse seu rumo, tudo na paz. Não podia é ficar forçado, inclusive porque atrapalhava o fluir das energias na casa. A filha de Ogum ficou visivelmente incomodada com as palavras do caboclo. Depois eu soube que na manhã seguinte ela foi procurar Jandira, chorando. "Mas o que foi, menina?" - Jandira teria perguntado. "É que meu pai chamou todo mundo pra dar sermão, e eu vesti a carapuça porque tinha culpa no cartório". Jandira então contou que ela se desculpara, justificando que falara aquilo em um momento de raiva, porque tinha ciúmes da atenção que a mãe dava às outras filhas.

Em muitos aspectos a história de Jandira aproxima-se das histórias de Curió e Ritinha. Diferente destes, entretanto, ela logrou canalizar a energia 
dos orixás para sustentar sua autoridade como líder de um terreiro relativamente bem-sucedido. É possível tomar os três casos como representativos de pontos diferentes em uma trajetória típica de formação de liderança no candomblé: Curió, recém-iniciado; Ritinha, estabelecendo gradativamente uma relação próxima e duradoura com caboclo e clientes; Jandira, uma liderança consolidada. Separando-os estão diferentes tipos de compromisso com a religião, diferentes graus de conhecimento.

O conhecimento que Jandira adquiriu ao longo dos anos não é simplesmente uma maior familiaridade com o corpus de mitos e ritos do candomblé, senão também uma sensibilidade própria em relação a deuses e humanos. Seus orixás e caboclos não são forças genéricas que subitamente assumem controle sobre ela, mas parceiros com quem estabeleceu um vínculo duradouro, e que podem mediar suas conexões com outros e vir em seu socorro (como no caso do exu Pata de Ouro, que baixou em resposta à sua dificuldade para lidar com a situação de Curió), e cuja aproximação ela pode discernir através de qualidades sensíveis distintas.

Nas descrições de Jandira encontramos mais uma vez a idéia de que o poder infundido pelos orixás aos seus filhos humanos encontra raízes no passado. O passado fortalece Jandira, legitimando sua posição de mãe-desanto - afinal de contas ela é visitada pelos deuses desde a infância, e seu pai não só descende de africanos como tem um vínculo de nascença com os orixás. O discurso da ancestralidade africana, bem sabemos, tem grande significação na política interna do candomblé e nas relações que esta religião mantém com a sociedade mais ampla — serve para legitimar certos terreiros e desqualificar outros, afirmando o valor do candomblé como uma religião de preservação da tradição africana.

Assim, no que diz respeito ao tema da agência, a definição do passado, ao qual lideranças, seguidores e clientes se referem, não é questão simples do ponto de vista das ciências sociais. É possível explicar o passado, redescoberto por sujeitos e grupos pesquisados, como seleção e fabricação tendenciosa realizada do ponto de vista do presente - a história de Curió é mesmo quase uma lenda - e concluir que o papel da possessão é tornar plausível e sensível o eu ou a identidade futura que a religião almeja construir: forjando um passado comum e apresentando o futuro como seu resultado necessário, a possessão confere credibilidade a um estado desejável de coisas. Em outras palavras, e parafraseando Bourdieu, transforma estratégia em destino.

Entretanto, nos estudos, freqüentemente esta visão do passado - construção simbólica que serve para fortalecer lideranças e seguidores da religiãoé articulada a outra, bastante diferente, que visa responder à questão de 
por que certas pessoas ou grupos precisam recorrer à possessão. Aqui a análise dá uma guinada e apresenta o passado como uma cadeia objetiva de eventos transcorridos, de forças sociais e econômicas que determinam presente e futuro. Uma linha demarcatória é desenhada entre passado real e passado fabricado: ligado a este há o sujeito como agência, uma imagem de construção ativa do mundo; ligado àquele, um contexto de condições objetivas e uma imagem de submissão passiva. Interessante observar que em ambas as soluções a conexão que as pessoas mantêm com seu passado só pode ser externa: quer como criação ativa ou como conservação passiva, o passado é privado de seus elos vitais com a experiência social, conectado de fora ao vivido através de uma cadeia de causalidade (seja como origem, seja como efeito). Como resultado, há uma visão empobrecida do passado e de seu lugar nas histórias de possessão de adeptos do candomblé.

Vou voltar mais uma vez à reflexão fenomenológica sobre o corpo. Em um dos cursos que proferiu no Collège de France, Merleau-Ponty observou:

O problema da memória não tem saída enquanto se hesita entre a memória como conservação e a memória como construção. [...] [a] imanência e a transcendência do passado, a atividade e a passividade da memória não podem ser reconciliadas enquanto não renunciarmos a colocar o problema em termos de representação. Se, para começar, o presente não é mais "representação" (Vorstellung), mas certa posição única do índice do ser no mundo, se nossas relações com ele, quando ele desliza para o passado, como nossas relações com o entorno, são atribuídas a um esquema corporal que detém e designa uma série de posições e possibilidades temporais, se o corpo é quem a cada vez responde [à] questão: "Onde estou e que horas são", então não haverá mais alternativa entre conservação e construção ${ }^{7}$ (Merleau-Ponty 1968b:72).

Para Merleau-Ponty (1968b), só quando recuperamos o nexo entre memória e práticas corporais é que podemos transcender a alternativa entre tomar o passado como simples fabulação a serviço do presente ou concebê-lo como força exterior que determina o devir. O passado vigora no corpo enquanto conjunto de abordagens ao mundo, estas incorporadas aos gestos, às posturas, às expressões e às habilidades; assim nem é a operação de forças e condições externas, nem a criação de uma consciência que está sempre no presente. Há uma sedimentação do passado no corpo - não apenas de um passado pessoal, mas de um passado coletivo (idéia que pode ser encontrada no conceito de técnicas corporais de Mauss e no conceito de "habitus" de Bourdieu). 
Nesta direção, agora de volta aos estudos sobre possessão, Stoller fala de uma memória cultural incorporada, que tem um status bem distinto de uma produção textual acerca do passado. A memória incorporada remete a um saber fazer relativo ao domínio do hábito, que Connerton define como "capacidade de reproduzir uma determinada ação" (1993:27). Entre os Songhay do Níger, observa Stoller, os ritos de possessão são um exemplo vivo da operação deste tipo de memória. Ao fazer eclodir no corpo o passado, a possessão reativa sua potência, criando "uma arena fenomenológica na qual a memória cultural é fabricada e refabricada para produzir e reproduzir poder" (Stoller 1997:56). Ao evocar o passado através dos sentidos, a possessão dos Songhay manipula o presente e provoca o futuro (1997:65).

Estas observações ajudam-nos a entender melhor o poder que as imagens religiosas podem apresentar para seus seguidores: elas ressoam em seus corpos, por vezes trazendo de volta certos modos habituais de se posicionarem diante dos outros e das coisas; adensam essas experiências, somando-se a elas e abrindo-as para novas situações. O passado que Curió, Ritinha e Jandira recuperam e com o qual se vinculam através da possessão não é apenas um conjunto de representações, mas também possibilidades de agir e relacionar-se que pertencem a uma história compartilhada. A descoberta de que esse passado retém vigor no corpo é tanto recepção passiva mostra que eles são herdeiros de uma história que não escolheram quanto criação ativa - pois abre um caminho de ação no futuro.

Embora não seja acessível a todos, a possessão no candomblé é emblemática dos laços que são firmados com as entidades sagradas e dos modos com que o corpo se torna acessível a elas. É uma forma de prática importante e altamente valorizada, objeto de novas elaborações à medida que progride o envolvimento dos sujeitos com a religião e as relações com as entidades se tornam mais rotineiras. A possessão, quando ligada inicialmente à aflição, emerge como uma experiência de ritmo que assume o controle do corpo os espasmos de Ritinha e os soluços de Curió - e sintetiza e amplifica uma condição existencial mais geral, lançando-a para frente, em direção ao estabelecimento e ao cultivo de laços com as entidades, e jogando-a para trás, em direção ao reconhecimento e à aceitação do passado.

\section{Conclusão}

Neste trabalho, foram examinadas três histórias de possessão desenroladas no contexto do candomblé de Salvador. Ao discutir essas histórias, procurei mostrar como uma reflexão fenomenológica sobre a constituição temporal 
da prática pode contribuir para uma melhor compreensão da possessão. Esta reflexão levantou três pontos inter-relacionados que são particularmente relevantes: 1. o jogo entre passividade e atividade na construção da agência via possessão; 2. a dimensão encarnada da possessão como prática dotada de sentido; e 3. a elaboração mútua entre passado e futuro no desenrolar da experiência com as entidades espirituais.

A título de conclusão, gostaria ainda de sugerir que se uma reflexão sobre a teoria da prática nos ajuda a esclarecer elementos fundamentais acerca da possessão, o recurso à possessão como caso exemplar para discutir a teoria da prática pode também trazer ganhos importantes para tal teoria. Por ser um exemplo pouco usual nas discussões sobre prática, pode nos levar mais facilmente a uma atitude de estranhamento em face de alguns pressupostos não examinados da teoria.

Tomemos o tema da agência e consideremos a pergunta: de quem é mesmo a agência que é articulada na prática? Aqui nosso caso exemplar ajuda a desconstruir a noção corrente de que agência deva ser definida a partir de noções como intenção ou interioridade - afinal, na possessão, a agência não apenas é distribuída entre espíritos e humanos como também só se afirma na articulação entre passividade e atividade. A questão do significado é igualmente exposta à crítica quando aplicada ao estudo da possessão. Nesta modalidade de prática — em que os limites entre consciência e inconsciência são tênues e flutuantes — o sentido não pode residir em um ato de vontade, em uma escolha prévia do sujeito. De fato, uma vez que as noções de consciência, decisão e cognição se mostram minimamente deslocadas, a teoria pode ser mais facilmente conduzida a pensar o sentido em sua conexão com a encarnação, bem como a abdicar da pretensão de "localizar" o significado em um ato criador para tomá-lo enquanto processo em curso de retomada e posterior elaboração de um sentido, sempre presente, mas também sempre inacabado.

Por fim, é possível ainda dizer que a possessão oferece um bom exemplo para tratar da questão da causalidade, ou melhor, da utilidade de modelos causais para o entendimento da prática. Isto porque, no caso da possessão, as teorias que procuram suas causas em um passado de condições - desigualdades sociais, assimetrias de poder ou mesmo estruturas psíquicas — têm que enfrentar a utilização explícita de um discurso sobre o passado pelos próprios "nativos", freqüentemente duplicando o sentido do termo (de um lado, o passado é determinação ou causa; de outro, é construção ou efeito). A oscilação entre estes dois sentidos expõe a fragilidade dos modelos sobre os quais repousam e da noção mesma de temporalidade que os embasa. Conforme argumentei, o tempo da prática não pode ser entendido como 
uma cadeia de causas e efeitos. Passado e futuro (passividade e atividade, repetição e criação) elaboram-se mutuamente: a prefiguração do futuro no passado é também busca e reativação do passado no futuro. E assim voltamos à questão da temporalidade.

Recebido em 04 de maio de 2007

Aprovado em 21 de agosto de 2007

Miriam Rabelo é professora do Departamento de Sociologia e do Programa de Pós-Graduação em Ciências Sociais da Universidade Federal da Bahia. E-mail: mcmrabelo@uol.com.br.

\section{Notas}

${ }^{1}$ Este ponto é retomado nas seções seguintes, nas quais discuto a dinâmica temporal da experiência em conexão com sua dimensão encarnada fundamental.

${ }^{2}$ No caso de Ritinha, esta dinâmica inclui também modos de resistência à perda da agência e ao desenvolvimento de formas de atenção e controle do corpo.

${ }^{3}$ Equedes são mulheres, membros efetivos de um terreiro, que não vivenciam a possessão. Seu papel no terreiro é cuidar dos orixás e de suas filhas e filhos incorporados (enxugando-lhes o suor do rosto, ajeitando as roupas do orixá enquanto ele dança ou, quando necessário, mandando embora o santo do corpo do médium humano).

${ }^{4}$ Sentido, como o próprio termo sugere, é antes de mais nada direção: é gestado no movimento através do qual uma experiência recupera o passado e aplica-o ao futuro (conforme já notamos na seção anterior).

${ }^{5}$ Abiku é uma palavra yoruba que significa "aquele que nasce para morrer". Refere-se a pessoas que têm um vínculo muito frágil com a vida: não importa quantas vezes venham a renascer, as crianças abiku sempre estarão próximas da morte. No candomblé, os abiku não podem nem devem ser iniciados - o que, segundo Lépine, pode ser entendido à luz da associação simbólica entre iniciação e morte: iniciar uma pessoa que já está perigosamente próxima da morte é colocar sua vida em risco. Como muitos outros adeptos do candomblé, Jandira não conhece o sentido original da palavra, que ela emprega para se referir a pessoas cujos laços com os orixás já foram selados de nascença e que, portanto, não precisam passar pelo processo de iniciação. 
${ }^{6}$ Erês são entidades infantis, de comportamento brincalhão e irreverente, ligadas aos orixás (cada orixá tem seu erê pessoal). O estado de erê é descrito como um transe suave que medeia entre a possessão pelo orixá e o estado de vigília. Jandira referese à importância dessa mediação para aqueles que não estão ainda acostumados e preparados para receber a energia forte dos orixás.

${ }^{7}$ No original: “Le problème de la mémoire est au point mort tant on hésite entre la mémoire comme conservation et la mémoire comme construction. (...) L'immanence et la transcendence du passé, l'activité et la passivité de la mémoire ne peuvent être réconciliées que si l'on renonce à poser le problème en termes de représentation. $\mathrm{Si}$, pour commencer, le présent n'était pas 'représentation' (Vorstellung), mais une certaine position unique de l'index de l'être au monde, si nos rapports avec lui, quand il glisse au passé, comme nos rapports avec l'entourage spatial, étaient attribués à une schema postural qui détient et désigne une série de positions et possibilités temporelles, si le corps est qui répond chaque fois a la question: 'Où suis-je et quelle heure est-il', alors il n'y aurait pas d'alternative entre conservation et construction..." (Merleau-Ponty 1968b:72).

\section{Referências bibliográficas}

BIRMAN, Patrícia. 2005. "Transas e transes: sexo, gênero nos cultos afrobrasileiros, um sobrevôo". Estudos Feministas, 13(2):403-413.

BASTIDE, Roger. 1973. "Cavalos dos Santos (esboço de uma sociologia do transe místico)". In: Estudos afrobrasileiros. São Paulo: Perspectiva. pp. 293-323.

. 1985. As religióes africanas no

Brasil. São Paulo: Livraria Pioneira Editora.

BODDY, Janice. 1989. Wombs and alien spirits. Women, men and the Zar cult in northern Sudan. Madison: The University of Wisconsin Press.

CAPRARA, Andrea. 1998. "Médico ferido: Omulu nos labirintos da doença". In: P. C. Alves e M. C. Rabelo (orgs..), Antropologia da saúde: traçando identidade e explorando fronteiras.
Rio de Janeiro: Relume Dumará/ Fiocruz. pp. 123-138.

CONNERTON, Paul. 1993. Como as sociedades recordam. Oeiras: Celta Editora.

CORIN, Ellen. 1998. "Refiguring the person: the dynamics of affects and symbols in african spirit possession cult". In: M. Lambek e A. Strathern (orgs.), Bodies and persons: comparative perspectives from Africa and Melanesia. Cambridge: Cambridge University Press. pp. 80-102.

CRAPANZANO, Vincent. 1977. "Introduction to case studies of spirit possession". In: V. Crapanzano e V. Garrison (orgs.), Case studies of spirit possession. New York: John Wiley. pp. 1-40. .1992. Herme's dilema and Hamlet's desire. On the epistemology of in- 
terpretation. Cambridge: Harvard University Press.

KELLER, Maria. 2002. The hammer and the flute: women, power and spirit possession. Baltimore: The John Hopkins University Press.

KRAMER, Fritz. 1993. The red fez: art and spirit possession in Africa. London: Verso.

LAMBEK, Michael. 1981. Human spirits: a cultural account of trance in Mayotte. Cambridge: Cambridge University Press.

1993. Knowledge and practice in Mayotte: local discourses of Islam, sorcery and spirit possession. Toronto: University of Toronto Press.

LÉPINE, Claude. 1978. Contribuição ao estudo da classificação dos tipos psicológicos no candomblé Ketu de Salvador. Tese de doutoramento, Departamento de Ciências Sociais, Faculdade de Filosofia, Letras e Ciências Humanas, USP, São Paulo, mimeo.

MAHMOOD, Saba. 2001. "Feminist theory, embodiment and the docile agent: Some reflections on the egyptian islamic revival". Cultural Anthropology, 16(2):202-236.

MASQUELIER, Adeline. 2001. Prayer has spoiled everything: possession, power and identity in an islamic town of $\mathrm{Ni}$ ger. Durham: Duke University Press.

MERLEAU-PONTY, Maurice. 1968a. "'L'Institution' dans l'histoire personelle et publique". Résumés de Cours (Collège de France, 1952-1960). Paris: Gallimard. pp. 59-65.

1968b. "Le problème de la passivité: le sommeil, l'inconscient, la mémoire". Résumés de cours (Collège de France, 1952-1960). Paris: Gallimard. pp. 66-76. .1994. Fenomenologia da percepção. São Paulo: Martins Fontes.

MIYAZAKI, Hirokazu. 2000. "Faith and its fulfillment: agency, exchange and the fijian aesthetics of completion". American Ethnologist, 27(1):31-51.

PRANDI, Reginaldo. 1991. "A religião e a multiplicação do Eu: transe, papéis e poder no candomblé". Revista USP, março/abril/maio:133-144.

SLAVIN, Sean. 2003. "Walking as spiritual practice: the pilgrimage to Santiago de Compostela". Body \& Society, 9(3):1-18.

STOLLER, Paul. 1997. Sensuous scholarship. Philadelphia: University of Pennsylvania Press.

TAMBIAH, Stanley S. 1981. A performative approach to ritual. Proceedings of the British Academy, v. LXV. London: Oxford University Press. 
Resumo

A idéia de que a possessão deve ser tratada como uma modalidade de prática tem estado presente, embora segundo elaborações diversas, nos trabalhos de vários antropólogos contemporâneos. Este texto tem como objetivo discutir alguns pontos teóricos relevantes para um entendimento da possessão como prática: a questão da agência, a das relações entre corpo e significado e a da temporalidade. Nele, partindo de uma abordagem fenomenológica, desenvolvo o argumento de que um tratamento apropriado destas três questões requer atenção à constituição temporal da prática (neste caso, da possessão). Mais especificamente, argumento que a falta de uma reflexão sobre a temporalidade pode conduzir a sérias distorções na análise da possessão. No texto, esta reflexão é desenvolvida através do exame de três histórias de possessão no candomblé de Salvador.

Palavras-chave: Possessão, Prática, Agência, Encarnação, Temporalidade
The idea that possession should be treated as a modality of practice has been found in a variety of forms in the works of a number of contemporary anthropologists. This article discusses a series of theoretical points central to understanding possession as practice: the questions of agency, the relations between body and meaning, and temporality. Pursuing a phenomenological approach, I attempt to show that any adequate treatment of these three questions requires that we attend to the temporal constitution of practice (in this case, possession). More specifically, I argue that failing to include temporality as a factor may seriously distort our analysis of possession. This thesis is developed through an examination of three case histories of possession in candomblé cults in Salvador, Bahia.

Key words: Possession, Practice, Agency, Embodiment, Temporality 